\title{
Sexo-s en el lupanar: Un documento fotográfico (circa 1940)
}

\begin{abstract}
Dora Barrancos e Ricardo Ceppi ${ }^{* *}$
Un acontecimiento fortuito permite el rescate de otro acontecimiento por cierto menos fortuito, ya que en este caso se revelan aspectos del intercambio explícito de servicios sexuales en un ambiente cuya antigüedad institucional es regular y se confunde con el origen de los tiempos. Es fortuito el hallazgo del documento que registra conductas sexuales, pero convengamos que lo es mucho menos la persistencia de la institución que lo hizo acontecer. Lo más extraño en todo caso es la sobrevivencia de la serie fotográfica que permitió la captura de los juegos lascivos que analizaremos; todavía queda la interrogación sobre la índole del propietario, o mejor, del productor de las imágenes y se abren preguntas sobre el significado de su resguardo. Pero ingresemos a la historia de este acontecimiento.

Una adolescente se depara por azar, en la calle, con los restos de una mudanza. Entre los trastos abandonados un conjunto de cilindros denuncia la existencia de negativos fotográficos que constituyen una parte esencial de la materia de trabajo de su padre, que casualmente es un fotógrafo profesional. La adolescente - animada por su madre - decide hacerse con los cilindros que pueden interesar y agradar a su padre. Es así como este acto azaroso subvierte el destino de la pérdida inexorable para ingresar al estatuto del documento: el fotógrafo revela la serie que permite reconstruir - o mejor imaginar con condescendencia histórica - las escenas transcurridas en un lupanar de baja categoría, casi ciertamente en algún paraje semirrural de la pampa
\end{abstract}

\footnotetext{
* Recebido para publicação em março de 2005, aprovado em maio de 2005.

** Dora Barrancos es la Directora del Instituto Interdisciplinario de Estudios de Gênero, Buenos Aires, Argentina. Dora1508@aol.com
} 
húmeda argentina, o por lo menos en los extramuros de algún pueblo en esa región.

Se trata de treinta siete exposiciones insólitas que el fotógrafo de marras decide compartir con especialistas y no tanto. En esa búsqueda se encuentra con la historiadora y he aquí los resultados del escudriñamiento que opera, necesariamente, sobre una trama hipotética, comenzando por la identidad de quien(quienes) realizó(aron) este documento en un momento en que, como se verá, se inicia la difusión de la cámara fotográfica entre los sectores acomodados y medios de nuestra sociedad. La disposición de la nueva tecnología constituye una verdadera revolución para represar imágenes en actos que parecen conferir mayor soberanía a los individuos. Sin duda está en juego una tecnología que inicialmente, y por bastante tiempo, usufructan los varones de la familia haciendo a menudo la voluntad de las mujeres y en la que descuellan los retratos familiares. ${ }^{1} \mathrm{La}$ fotografía opera en base a una división sexual de tareas durante su propagación: la máquina fotográfica indexa funciones calificadas a los varones y sus resultados, las fotografías, demandan colección y archivo por parte de las mujeres. Salvo aquellas que corresponden a órdenes prohibidas, mantenidas en secreto, o mejor sólo disponibles para públicos estrictamente seleccionados. De su resguardo archivístico por cierto han debido ocuparse los varones y tal parece haber sido la suerte de este documento.

Hipotetizando acerca de la conducta de actores y actrices

La cámara fotográfica tiene la ventaja de servir a una inflexible temporalidad: la sucesión de imágenes es irrevocable desde la perspectiva de quien las produce. La posibilidad de burlar el orden de la gestación sólo puede ser obra de los/las receptores y el trucaje obtiene entonces una expedita autorización. La fidelidad

\footnotetext{
1 Para un análisis de la evolución fotográfica en ámbito s familiares y domésticos, remitimos a SILVA, Armando. Album de familia. La imagen de nosotros mismos. Editorial Norma, Bogotá, 1998.
} 
a la sucesión original de los acontecimientos que habrán de ocuparnos, está en nuestro caso garantizada y por lo tanto haremos, en primer lugar, una traducción especular de los actos tal como ocurrieron según un orden temporal. Esas imágenes se traducen en narrativas, en textos vívido. La descripción es indispensable para anclar una analítica comprehensiva aunque habremos de detenernos sólo en algunas escenas, aquellas que entrañan según los criterios de nuestra selección, una mayor centralidad semiológica.

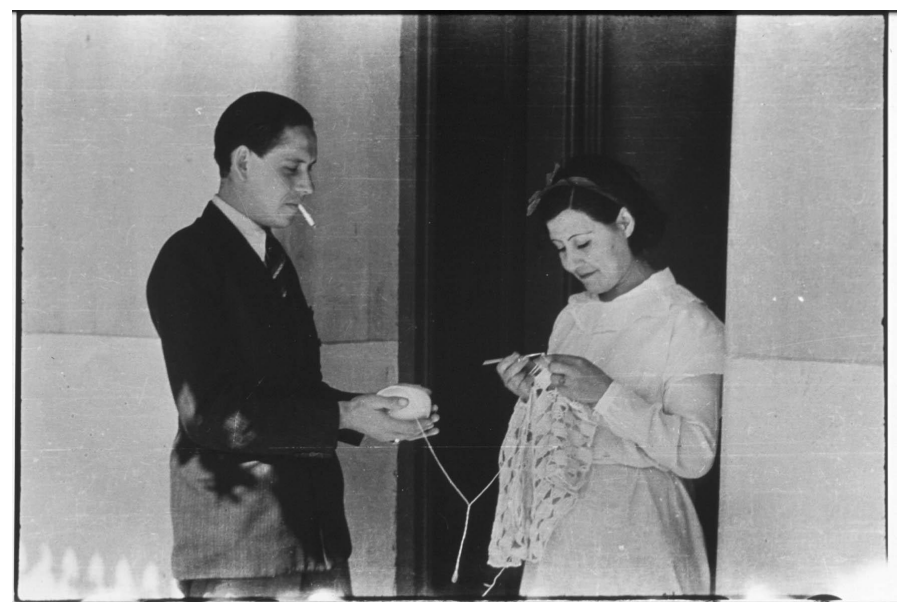

Las dos primeras imágenes no son capaces de anticipar, absolutamente, la saga sexual sobreviniente. Una mujer joven, bastante bonita, con vestido largo y de color claro (de difícil identificación epocal, pues tiene aires de veste supratemporal) patentiza un consabido rol genérico tejiendo crochet, enmarcada por una puerta que invita al ingreso. Es evidente que en el momento de la toma la cámara la ha distraído, sus ojos miran de modo oblicuo y parece querer convencer sobre cierto ensimismamiento. Su postura es displicente, pero parece retraída en la labor. El ovillo del material que trabaja permanece en el suelo hasta que la acción ejercida por un hombre joven y bello, 
rigurosamente bien trajeado y engominado, con cigarro en la boca - en una ambigua actitud contrafóbica -, lo sostiene en clara actitud de cooperante con la joven tejedora. Tal la escena segunda de esta saga. La conducta reverente de las virtudes femeniles en artes que le son tan compatibles, sólo subraya el carácter varonil dominante de la relación entre los géneros coagulada en esta imagen.

Deben haber mediado una serie de acciones que seguramente consumieron más que algunos minutos, hasta la instalación en foco del tercer acto: el joven de marras se muestra besando y acariciando a una mujer joven sentada sobre su muslo. La mano del hombre acaricia el pubis, mientras la muchacha le toma la cara. Los ojos de ambos actores permanecen cerrados y esta es la única escena que orilla la gestualidad propiamente erótica de la serie. Se cuela ya la impresión de que ingresamos a un documento peculiar, que estamos frente a un registro de clara urdimbre sexual.

A parece luego una escena que registra a otros dos varones conversando en el vano de una puerta con una tercera mujer que luce algo mayor, vestida de entre casa con un largo salto de cama rayado y de aspecto ordinario, presumiblemente confeccionado con tela de toalla y que evoca usos del período. El salto de cama, que se instala sobre todo como moda femenina, comporta una estricta jerarquía de gustos una de cuyas claves es el material. Las sedas están en el orden alto de las preferencias, mientras que las toallas se ubican en la escala inferior: su uso se confunde con el que se destina a secarse el cuerpo, y estrictamente es más rústico, no seduce como la seda, que insinúa más eficazmente el cuerpo velado.

Uno de los varones que usa anteojos y se muestra en mangas de camisa, gesticula; hace ademán de señalar, con una de sus manos, una altura, mientras el otro lo observa. Este último sostiene un diario de actualidad doblado bajo el brazo, detalle que seguramente indicia que está de "acompañante", que no está decidido a un protagonismo marcante, ya que no se ha tomado el 
trabajo de despojarse del periódico. Esta escena donde parecen intercambiarse trivialidades mediante órdenes de locuciones contingentes, no consigue distraer a la pareja que nos ocupa que seguramente ha proseguido con los intercambios de caricias. ¿Esta foto de márgenes de conversación, es una pose para retirar intensidad a las escenas centrales de sexo? En las tomas siguientes se revela la incursión de las manos del muchacho en las piernas de la joven, haciendo subir la pollera hasta una completa exposición de aquellas. Se advierte que están vestidas hasta las rodillas con medias "de seda", a la usanza del período, a las que ciñen unas insinuantes aunque escasamente eróticas ligas. En la foto siguiente, la joven, que mantiene abrazado al muchacho mientras se deja acariciar la zona del pubis, contempla de modo directo la cámara con una insinuación de sonrisa que funge como atención desplazada al "otro entretenimiento".

Todos estos actos son apenas la introducción al rito central de la masturbación captada por la cámara que, convengamos, es acometida por un asomo de autocensura. El fotógrafo ha ahorrado demoradas y más atrevidas tomas intermedias de modo que sólo una fotografía - sin duda central en el documento - pone en evidencia la serie de maniobras masturbatorias que han debido ejecutarse y su resultado, la eyaculación. El artefacto "eyacula" exactamente a tiempo, coincidiendo con la acción que capta. ${ }^{2}$ ¿Ese detenido voyerismo del fotógrafo que la imagen denuncia, ha significado efectivamente un involucramiento trascendiendo el goce del acto de manipular la cámara? La asombrosa nitidez de las gotas seminales de esta única escena de sexo explícito del documento que tratamos, habla más que de las propiedades de la sensualidad de los cuerpos, de los atributos técnicos de la cámara. Es aquí que se hace necesario un primer estacionamiento para introducirnos en contextos necesarios a la interpretación.

\footnotetext{
${ }^{2}$ Debo Diana Maffía la sugerencia de sentido, en torno de este doble acto eyaculatorio.
} 


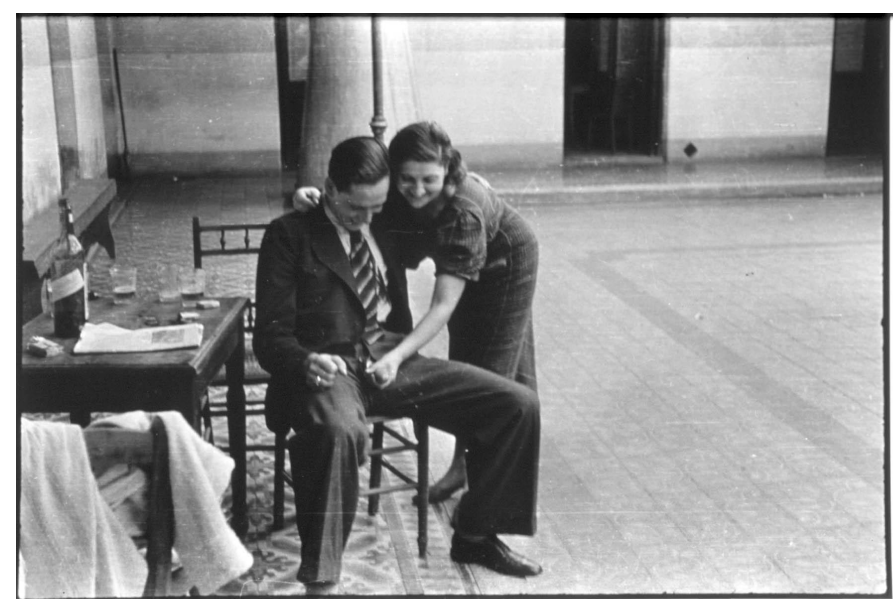

No hay dudas de que estas fotografías no revelan la intimidad de una pareja canónica de fines de los años 1930 - o casi seguro de inicios de los 40 -, sino que desnudan el trámite habitual de una visita a otra regularidad, debidamente reticulada en la simbología corriente de los intercambios necesarios para satisfacer a los varones, el prostíbulo. ${ }^{3}$ Es probable que algunos

3 Ver especialmente GuY, Donna. EI Sexo peligroso: la prostitución legal en Buenos Aires, 1875-1955. Buenos Aires, Editorial Sudamericana, 1994; CorBIN, Alain. Les filles de noce. Paris, Aubier Montaigne, 1978; RAGO, Margareth. Os Prazeres da noite: prostituição e códigos de sexualidade feminina. Rio de Janeiro, Paz e Terra, 1991; B LISS, Katherine Elaine. Prostitution, Revolution and Social Reform in Mexico City, 1918-1940. Tese de Doutorado, University of Chicago, 1996; Pereira, Cristiana Schettini. Um gênero alegre: imprensa e pormografia no Rio de J aneiro (1898-1916). Dissertação de mestrado, História Social, Unicamp, 1997; BRISTOw, Edward. Prostitution and prejudice: the jewish fight against white slavery, 1870-1939. Oxford, Oxford University Press, 1982; ESTEVES, Martha de Abreu. Meninas perdidas: os populares e o cotidiano do amor no Rio de J aneiro da belle époque. Rio de J aneiro, Paz e Terra, 1989. Un estudio clásico es el HenRIQuez, Fernando. Prostitution and Society. 3 Vol, "The Pretence of Love", "The inmoral Tradition" and "Modern Seuality", London, MacG ibbon and Kee, 1962-1968. El tratamiento de la prostitución en la literatura ha sido tratado, entre otros, por Seymour-Smith, Martín. Fallen Women. London, Nelson, 1969. Un abordaje poco convencional "desde" las mujeres que 
excéntricos documentaran fotográficamente sus experiencias sexuales con parejas regulares, legales o legítimas. Pero debemos concluir que eso constituye una rareza aún mayor, una nota improbable en los moldes morales afirmados en la doble trinchera de los códigos. El canon moral alienta la idea de que la ilustración de los cuerpos mostrando sus atributos sexuales, su exhibición captada por medios imagéticos, sólo se reserva a las mujeres que son capaces de transgredirlo, y no cabe dudas de que a estas se las llama prostitutas. Tal es el sema con que se representa a las que viven de desnudar su cuerpo, las modelos que sirven a pintores y retratistas, y qué decir de las actrices de cine - medio notablemente empinado por entonces - que se arriesgan a la interpretación de escenas más osadas con cuerpos que insinúan toda desnudez provocando estrépito entre sus seguidores/as. Todas ellas son "putas" en la extendida reducción semiológica del período, como lo son las trabajadoras que ofrecen gastar sus cuerpos en tareas extradomésticas, las "fabriqueras" y aún las empleadas de ciertos servicios. ${ }^{4}$ El "abandono" del hogar para salir a trabajar es una mala imagen, no rinde, definitivamente, buena reputación cualquiera que sea el ámbito donde se transite. Seguramente entre las pocas mujeres que rodean con éxito el

ejercieron la prostitución es ofrecido por KUSHNIR, Beatriz. Baile de máscaras: mulheres judias e prostituição: as polacas e suas associaçõ es de ajuda mútua. Rio de Janeiro, Imago, 1996. No puede dejar de consultarse el trabajo pionero de Parent-Duchatelet, Alexander J. B. De la prostitution dans la ville de Paris considerée sous le rapport de l'hygiene publique, de la moral et de l'administration... Paris, Bailliere, 1936, especialmente la reedición bajo el nombre La prostitution a Paris au XIX siecle. Paris, Seuil, 1982, con introdudiccón de Alain Corbin, así como la obra de WALKowITZ, Judith Prostitution and victorian society: women, class and the state. Cambridge, Cambridge University Press, 1980, y WALKO WITZ, J udith City of dreadful delight: narratives of sexual danger in late Victorian London. Chicago, University of Chicago Press, 1992.

${ }^{4}$ Ver BarRancos, Dora. Moral sexual y mujeres trabajadoras en el perío do de entreguerras. In: MADERO, Fernando y MADERO, Marta. (Directores) Historia de la vida privada en la Argentina, T.3, Buenos Aires, Taurus, 2000. 
Sexo-s en el lupanar

inefable epíteto se encuentran las maestras, tal vez las únicas a las que les es permitido el goce con fruición de su tarea, ya que los signos de contentamiento por la vida laboral, aún la más jerarquizada profesional, suele ser un estigma más que un premio. ${ }^{5}$ Ser meretriz es el modo indexado que corresponde a cualquier asomo de riesgo de pérdida de las virtudes cardinales de "ser mujer" en nuestras sociedades hasta bien mediado el siglo que acabamos de dejar.

De modo que parece redundantemente evidente que estamos frente a fotografías tomadas en una arena pública especializada, ajustada a la otra máscara de la moral, pero que bien observada también luce como cuasi doméstica, propia para el regodeo del ojo sin máscaras, allí donde ceden los maquillajes y las pulsiones son incontinentes, como ocurre en el seno del hogar. El ambiente de este prostíbulo, escenario privilegiado de esta serie documental, no parece disentir de esos conocidos piringundines de bajos fondos, a menudo verdaderas fronteras ecológicas ya que se asientan en extramuros toda vez que transgreden las disposiciones abolicionistas de 1936. Si durante la época de la reglamentación se exigía su emplazamiento sólo en determinadas zonas, ${ }^{6}$ alejadas de escuelas y templos, al quedar prohibidos deben encontrarse sitios aún más aislados a cobijo de ojos indiscretos y de posibles denuncias. Seguramente la vista gorda de las autoridades policiales, casi siempre comprometidas con el negocio, exige esos distanciamientos. Desde luego están las

\footnotetext{
5 La descalificación de "puta" fue absolutamente común, ha atravesado todos los grupos sociales en sus más diversas composiciones ideológicas y políticas, y esto muy probablemente sea de constatación universal. Basta recordar que entre los anarquistas, la célebre J uana Rouco Buela - tan destacada por su militancia y por su autonomía al mantenerse como periodista y dirigir el periódico "Nuestra Tribuna"- también fue connotada como tal. Ver BARRANCOS, Dora. Mujeres de "nuestra Tribuna": El difícil oficio de la diferencia. Revista Mora, $n^{\circ} 2$. En la actualidad su uso directo ha inflexionado, sustituido por la elipsis "hijo de puta".

" La bibliografía que narra la experiencia "reglamentaria" de la prostitución es redundante sobre la dimensión normativa de la espacialidad, también sobre sus infracciones.
} 
excepciones, las casas de cita ${ }^{7}$ para las clases privilegiadas que se escamotean bajo disfraces los más caprichosos pero que seguramente sólo consiguen entera impunidad en el corazón de las grandes ciudades.

La escena de la masturbación coagula la escenificación del comercio sexual visto por este lente. De técnicas lascivas múltiples y sofisticadas, he aquí la reducción a una sola tecnología. La mecánica del acto al que se asistió entonces (y al que reasistimos por la reproducción) no debe sorprender por su carencia: está vaciado de erotismo, faltan los juegos de i-realización que constituyen los senderos del goce. La postura de la oficiante denuncia que la acción de manipular el pene, realizada de pie por la joven, apenas apoyada sobre el cuello del cliente, y que consiente el voyarismo de un reducido público - pero con todos las propiedades de los espectadores directos -, y al más amenazante ojo censor de la cámara que la apunta, reduce casi por entero los atributos eróticos del sexo en el lupanar de esta serie. Nos es esquiva la desnudez de los cuerpos, la imprescindible entrega fusional y esa característica transformación de los seres que los lleva al éxtasis, a la "continuidad animal" y esencialmente

\footnotetext{
7 Sobre la magnificencia de las casas de citas de los sectores altos, puede también caerse en estereotipos poco coincidentes con la realidad. Vale la pena traer al análisis un episodio ocurrido en México. Un notable coleccionista, Ava Vargas, se depara con una colección de desnudos femeninos producidos muy probablemente a fines de los años 1910, inicios de los 20. El conjunto es notable y parece delatar el contexto de su barroca producción: una casa de citas de muy alto nivel en seguramente la ciudad de México. Vargas publica una primera parte de estos desnudos en Londres, a cargo de Quarter Books en 1986. En oportunidad de la aparición de un segundo juego de fotografías (que evidentemente completaban la misma colección) las publicó en México, bajo el título "La casa de citas en el barrio galante" - Grijalbo, 1991-, antecedido de un prólogo del notable crítico Carlos Monsivais quien analiza ese tipo especial de acomodación "para la industria del objeto sexual". Sin embargo, Alfonso Sánchez Arteche ha descubierto la simulación de ese contexto: no se trataría, absolutamente, de una Casa de Citas, sino de un locus especialmente contextuado para fraguar esa idea. Ver ARTECHE, Alfonso Sánchez El ser y el parecer. Revista Universidad de México, UNAM, n.615, sept. 2002.
} 
a lo prohibido que según Bataille ${ }^{8}$ es indispensable en el canon erótico. Siguiendo a este autor podríamos sugerir que la mecánica sexual a la que asistimos es la culminación de la "rancachela" colectiva cuyo goce carnal es escueto, comparado con el acto de portar la cámara fotográfica. Se trata de un acto que se ejercita según el mismo Bataille, como "erotismo inhibido" o - agregamos - como remedo erótico. No en vano Bataille se refiere a estas circunstancias cuando introduce la "prostitución de baja estofa" y se refiere a quien la ejerce:

Podría ser menos indiferente a las prohibiciones que el animal, pero impotente como es para conseguir la perfecta indiferencia, sabe de las prohibiciones que otros observan; y no solamente está destituida, sino que le es conferida la posibilidad de conocer su degradación. Se sabe humana. Incluso sin tener vergüenza, puede ser conciente de que vive como los puercos. ${ }^{9}$

Podríamos hipotetizar que esa destitución consciente, que se paga con el desparpajo, con la asumida falta de vergüenza, es la que permite a nuestra muchacha autorizar a ese grupo de varones ser la protagonista de la saga fotográfica, as de triunfo que - ella lo sabe muy bien - incrementará el alardeo en círculos de machos. Por qué justamente ella resulta la protagonista es insondable, aunque nos azuzan los interrogantes. ¿Habrá aceptado ser objeto del registro porque sus compañeras se negaron y alguna tenía que satisfacer el pedido de los varones? ¿Resultó ser "espontáneamente" la más atrevida frente a las reticencias de las otras o fue abordada por el fotógrafo - los fotógrafos? - porque estaba preindiciada como la más osada? ¿H abrá sido escogida en un acto absolutamente incidental?

El género femenino aparece en esta saga con todas las muestras de su inflexión desventajosa corriente. La muchacha ni

8 Batallle, G eorges. El erotismo. México, Tusquets, 1997

9 ID., IB., P.142. 
siquiera ocupa el papel de objeto-de-deseo ya que aparece más distante que el cuerpo-objeto-íntegro capaz de producir placer. Esta mujer se desgaja de su cuerpo y consigue dar, con las señales del apartamiento, una ficción de objeto. Además, su cómplice es la propia cámara fotográfica, tal vez - como ya se ha insinuado el verdadero objeto de placer de esta historia. La cámara facilita ese estado ausente, ya que se roba el foco de atención. Es la cámara y no el sexo "con" las mujeres lo que captura el sentido central de esta narrativa. La saga revela actos maquínicos poniendo a la propia máquina como plausible objeto pulsional.

Podría decirse que no es nuestra muchacha la que hace el servicio de esta masturbación que más bien "se" hace; el acto parece ya una representación, metarrepresentada por la imagen que ha podido conservarse. La pornografía (y este documento está lejos de serlo) no conserva también el desvelamiento irreductible de una erotismo que se niega como posibilidad? Examinando las fotografías pornográficas de la colección reunida por Koetzle y Scheid ${ }^{10}$ - un conjunto desinhibido que protagonizan sólo los cuerpos femeninos y en el que abundan explícitos enlaces lesbianos - no puede dejar de tenerse la sensación de que el erotismo apenas se sugiere sobre lo obsceno, algo que en verdad desean re-presentar las ingeniosas y estudiadas poses de las modelos protagonistas de la serie, en algún estudio de París en torno de los años 1920.

Regresemos a la teconología de la masturbación como fórmula de comercio sexual más corriente de lo que se nos antoja. El trabajo precursor de Parent Duchatelet ${ }^{11}$ la identifica entre los repertorios prostibulares, pero para el ojo de este notable analista esta forma de actuación constituía un auténtico "vicio". Es probable que la condena de las famosas "terrosas", que sólo comprometían partes de su cuerpo para facilitar el placer de sus

\footnotetext{
${ }^{10}$ KortZle Michel y Scheid, Uwe. Frivolidades parisinas. Köln, Benedikt Taschen Verlag GmnH , 1994 (edición en español).

${ }^{11}$ Parent-Duchatelet, A. J . B. De la prostitution... Op. cit.
} 
Sexo-s en el lupanar

clientes, se deba a la subyacente aunque no conciente convicción de que hay aún más partición/extrañamiento del cuerpo femenino, más perversión en el servicio, una vez que no se adecua por entero a la condición de objeto entregado por entero. Es bastante posible que el servicio de la masturbación no fuera sólo el inicial de una larga sesión de intercambios sexuales. ${ }^{12}$ Pudo significar, por su virtualidad en materia de aproximación corporal y por su rapidez, una inversión contingente y de fácil solapamiento. Hombres a quienes su condición de clase les impedía pagar servicios completos, o a los que por el contrario cierta condición expectable los llevaba a sorteos y elusiones (notables, dignatarios, párrocos) inquietos por la duración del trato, o marcados por la prevención a las enfermedades o por el miedo a entregas mayores, aspiraban sólo a sesiones masturbatorias. Es muy probable que eventuales aventuras colectivas - "francachelas" prolongadoras de las experiencias de adolescentes, hicieran a los varones demandantes de intervenciones apresuradas. A menudo debe haberse impuesto la jarana nerviosa de la incursión grupal sólo para obtener servicios masturbatorios. ¿No se trataba acaso de una gran transgresión, habida cuenta la larga y tenebrosa insistencia de padres, maestros, autoridades higiénicas y religiosas sobre los peligros del vicio solitario? Pero al mismo tiempo, ¿no menguaba acaso su iniquidad si se dividía con otras(os)? La verdad es que el onanismo compartido sólo paradojalmente puede ilustrarse como "vicio solitario". Nos falta mucho que revelar en materia de prácticas onanistas que nada tienen de solitarias, de las experiencias de intercambios sexuales que se realizan sin necesaria penetración.

\footnotetext{
${ }^{12}$ Ver especialmente LAQUeUR, Thomas. Solitary Sex: A Cultural History of
} Masturbation. N.York, Zone Books, 2003. 


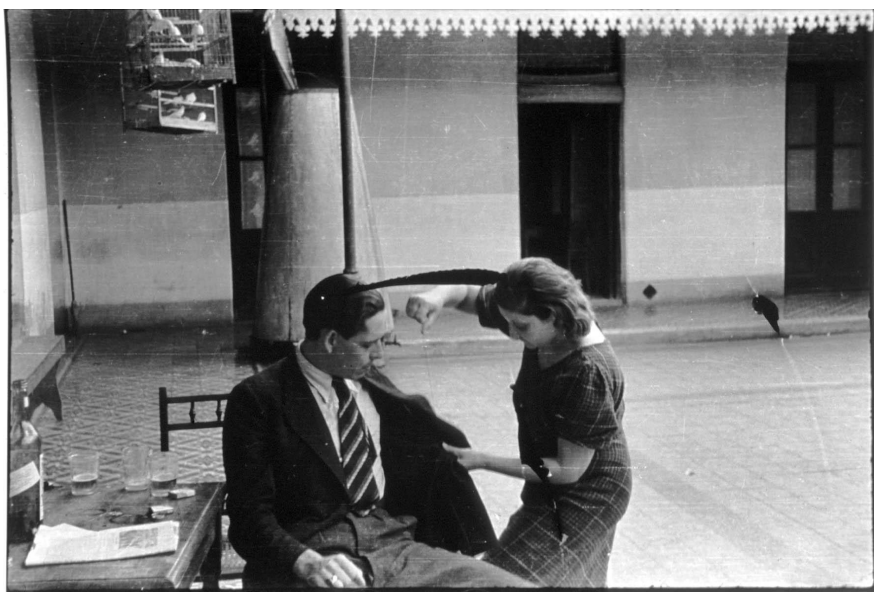

Pero volvamos a nuestro documento. Después de la escena de la masturbación, exponencial en la serie, aparece un par de tomas singulares pero no sorprendentes: la mujer cose un botón que ha advertido está a punto de caer del saco de su cliente. EI patetismo con que se diseña el congelamiento del oficio femenino es encomiable, tan verídico que parece una representación saturada, un "cliché". La mujer se comporta como una madre, o como una hermana en esa aptitud exponencial de velar por el varón bajo cualquier circunstancia. Si aisláramos de la saga a estas fotografías en la que la muchacha trabaja con el hilo y la aguja para asegurar el botón del joven - cuya edad pueda situarse entre los 25 años, tal vez -, las escenas parecen propias de cualquier ambiente doméstico en el que se imponen las reglas decentes de un auténtico hogar. Hay una culminación de tomas cuando la pareja se enlaza en un tierno abrazo, en un abrazo fraternal que traduce, de parte del varón, reconocimiento por la tarea reparadora, y de parte de la mujer, la convicción de que cumplió con una obligación. El trabajo enmendador que acaba de hacer la mujer y la nota de agradecimiento que emerge del abrazo enteramente asexuado que le prodiga el varón, nos conecta con los sistema de relaciones que también debieron 
Sexo-s en el lupanar

normalizarse en el interior de los propios prostíbulos. Nos referimos a ciertas canteras de amistad, de confidencialidad, a los brevísimos raptos de simetría entre los géneros a propósito de comprensiones menos subalternas que se establecieron en esos circuitos, tanto como a repertorios sentimentales que a veces culminaron con emparejamientos perdurables, rescates matrimoniales o cuando menos, con cuadros persistentes de asistencia monetaria o de otra naturaleza. Son incontables los casos que culminaron con relaciones afectivas, o cuando menos con intercambios desinteresados de amistad y protección.

La serie que estamos analizando focaliza a un grupo de hombres que visita un lupanar de extramuros munido de una cámara fotográfica con el expreso propósito de captar, como una hazaña, escenas iconoclastas, marcadas por la prohibición. Es por entero probable que ese rito haya respondido a la necesidad afirmativa - y por lo tanto forzosamente colectiva - de machos que, en este caso, remarcan no sólo su condición genérica, sino su clase social. Parecen en su mayoría miembros de la clase media empinada, de esa clase que mostraba las marcas del hedonismo con consumos más sofisticados, ávidos de nuevas tecnologías y adminículos. La tenencia de una cámara fotográfica Leica subraya esa pertenencia y más adelante volveremos sobre el significado de esta marca de clase.

En este grupo se destaca el joven de marras ya que es el actor dominante de la serie y a quien seguramente por alguna razón especial se desea agasajar, ofrecerle ritos celebratorios. Podemos conjeturar que se trata también, desde el punto de vista de la escala social, de uno de los mejor posicionados del grupo, o es mera apariencia? Hay un contraste entre su extrema urbanidad (el traje sastre oscuro riguroso, la corbata de finas y esparzas rayas, la camisa blanca, el calzado "social" reluciente) con la fisonomía y el aspecto de otro hombre, que aparece en otra toma, vestido a la moda campestre con pañuelo al cuello, boina, botas altas, y aunque en general luce con atildamiento, probablemente se trate de un encargado de campo; podemos conjeturar que es el 
verdadero introductor en el prostíbulo del grupo urbano, muy probablemente visitante acostumbrado que goza de amplia confianza en la "casa". Se trata del hombre-propulsor, mientras el joven celebrado podría marcarse como el hombre-señuelo. Casi no quedan dudas de que por lo menos algunos miembros de esta aventura están estrechamente vinculados con propietarios de bienes raíces, tal vez dueños de alguna estancia próxima al lupanar de marras, o con con otros eslabones del poder. ¿Podemos admitir que este atributo es la única marca de "prestigio" que revela este oscuro lupanar y lo que permite restablecer un sentimiento de "dignidad" a las pupilas? ¿No es ese sentimiento de "selección prestigiada" lo que allana también el camino para autorizar el uso de la cámara fotográfica? Si la "conciencia de clase" puede ser una traza en las subjetividades de tantas meretrices del período, no hay cómo engañarse al respecto: salvo contadas excepciones, la dignificación del servicio proviene de la calidad social de los servidos.

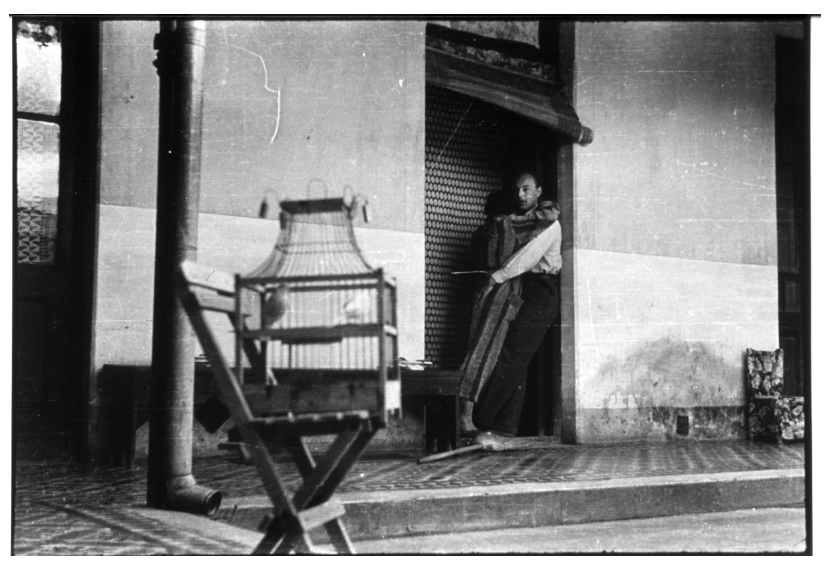

En esta serie el varón-promotor, al parecer tampoco se priva de un servicio masturbatorio: hay una fotografía que lo muestra al lado de una joven y atrayente mujer - la cuarta de este registro en actitud delatoria que puede ser imaginada pero cuya evidencia 
Sexo-s en el lupanar

no es posible corroborar. Esta pareja - y debido a los vínculos preexistentes que ligan al hombre con el lugar - ocupa las márgenes del registro documental y también las márgenes donde se juegan los episodios narrados centralmente por la cámara: un gran patio de baldosas, un patio típico que centraliza todos los contactos de las habitaciones (al parecer unas cuantas) y en el que se dispone por lo menos de una mesa de café, servida con copas y bebidas. Ese gran patio central alberga también una característica bomba de agua de pozo con un piletón y es decorado por una pajarera con un único habitante, tal vez un canario de alta estimación para las ocupantes femeninas de la casa. Era extendido el gusto por mantener en cautiverio canarios y otras aves de buen canto en esos años. Este detalle de la pajarera luce con la estridencia del adorno principal frente a la ausencia de frisos, cuadros y objetos kitch que podrían encontrarse en lugares aún poco sofisticados. En una vieja fotografia del interior de un prostíbulo de Gualeguaychú también una pajarera decora el ambiente. ${ }^{13}$ Pero la pajarera de este ámbito ha sido colocada ex profeso sobre una silla, tal vez a pedido del fotógrafo de marras, con qué intención? Es probable que para jugar con la escenografía, para medir técnicas y resultados y también para enmarcar una escena que transcurre en un rincón y que revela los abrazos y toqueteos de una pareja: la de la dama del largo salto de cama con uno de los visitantes, el que porta anteojos y al que ya vimos al inicio conversando animadamente y haciendo gestos.

\footnotetext{
${ }^{13}$ Se trata de una de las escasas fotografías que se han hecho circular sobre ambientes prostibularios en nuestro medio aparecida en Todo es Historia. Sección La fotohistoria del mes, Felicitas Luna, n³63, p.65.
} 


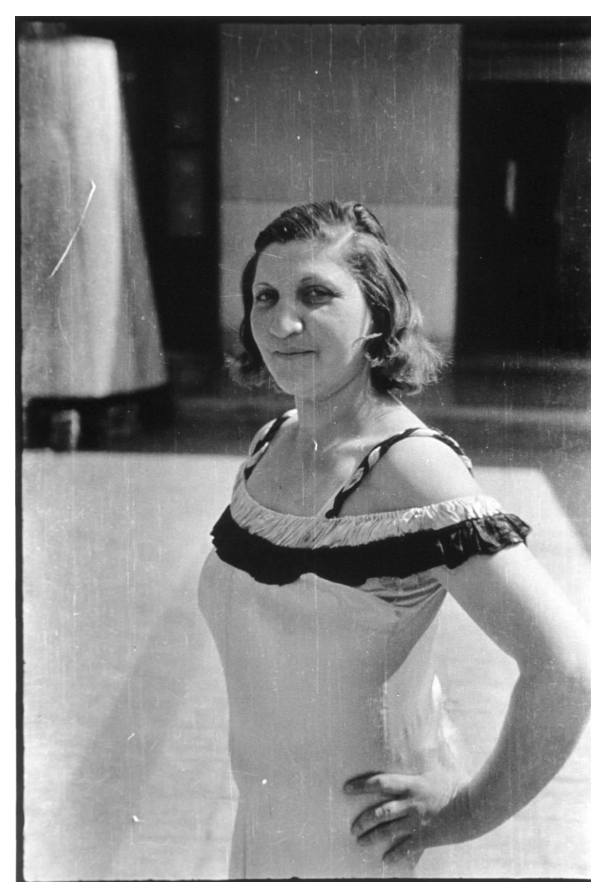

Es evidente que luego de los servicios sexuales el fotógrafo principal del grupo ha sido demandado para captar otras circunstancias. La muchacha que ha servido a nuestro joven protagonista seguramente ha insistido en que se le tomen otras fotografías, más "personales". Pretende estar a la altura de ese momento singular, todavía muy ritualizado, que no está precisamente signado por el orden de la profesionalidad en materia sexual, sino por el deseo de ser sujeto de un re-trato. ¿Un nuevo trato de sí que se despliega como un nuevo trato con los hombres? Entonces aparece vestida "de fiesta", ha ido a ponerse para una posteridad difusa - pero que adivina le sobrevivirá - tal vez el mejor vestido que luce su ropero. Se trata de un vestido largo, apretado al cuerpo, con una caída en los hombros, agarrados por unos breteles. El resultado es una pose de aire victorioso; el cabello recién peinado se destaca en la cabeza 
Sexo-s en el lupanar

echada un poco hacia atrás, y hay un gesto en el rostro, contenedor de una sonrisa, que luce como una carta de triunfo. ¿Triunfo por la suspensión del deseo del-otro, porque ha doblado la intención objetivista del otro, que finalmente la "narra" en una humanidad diferente, "normalizada" y dulcificada, como si le permitiera ser otra mujer?

Pero esta permisión termina, y en otras fotografías reaparece con el traje inicial, dispuesta a los hábitos regulares que como es de esperar comprenden otras tareas además de las profesionales. En efecto, varias fotografías la toman en escenas de limpieza del patio, comenzando por la de un tacho rectangular destinado a poner la basura que recogerá cuando termine de barrer el amplio patio.

Sobrevienen luego escenas casi familiares: hombres y mujeres se ven en actitud laxa y en clima de conversaciones cuyos objetos, podemos adivinar, se desafueran de las marcas del lugar. La cámara repara una vez más en la muchacha que ha ocupado con el joven el centro del teatro, y se la ve entonces seria, inclinada para sostener a un perro pequeño (que no había antes aparecido) sobre una silla. Desde un ángulo donde se observan trastos de limpieza, una mujer la mira con complicidad dulcificada, tal vez porque el animalito sea uno de los pocos seres de estimación de nuestra protagonista.

La casi veste de la primera aparición vuelve al escenario, ahora sentada pero sin abandonar la tarea del crochet; no parece haber sido partícipe de la rueda de servicios sexuales. Su lugar en el sillón esquivo refuerza el clima de prescindencia y de incontaminación que la serie le ha acordado. Habría que interrogarse sobre la necesidad narrativa de reestablecer al final, con la imagen de esta mujer con ropaje claro, el principio de apariencia incontaminada que ha abierto la serie. Es necesario apuntar al varón que se adiestra con la cámara mientras alarga su destreza social bajo el inconmovible acatamiento de la doble moral que admite la necesidad de las putas para preservar la honra de las verdaderas mujeres. 
Las fotos finales son patéticas por lo ajustadas a la representación, a la teatralidad. Actores y actrices van acomodando la despedida; una mujer ayuda a uno de los visitantes a ponerse el saco, escena que registra un acto que sin duda ha debido repetirse para que la cámara actúe "espontáneamente". Las manos extendidas de ambos sexos intercambian los adioses de modo tan descontextualizado que bien podría tratarse de una separación trivial en un patio familiar, en el de una escuela o una parroquia. Los sexos son o-puestos en su lugar gracias a una separación ascéptica que devuelve los seres a sus esferas correspondientes y los géneros a sus marcas asintóticas.

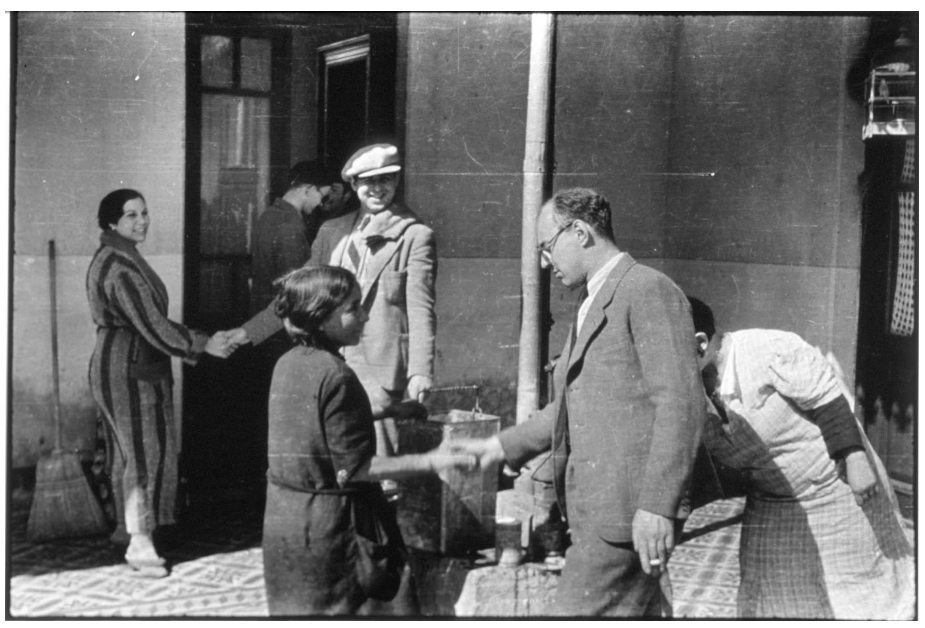

La serie va extinguiéndose con una fotografía que pone en foco a una parte de los varones mientras sale de la modesta casa de extramuros. Finalmente nos es dado conocer aspectos del edificio: el frente es un frente típico de nuestras construcciones semirrurales con paredes altas de ladrillos expuestos, donde sólo una ventana con persiana deja atravesar la luz ya que las otras tres o cuatro han sido tapiadas. La fachada es casi inocente en su 
Sexo-s en el lupanar

austeridad, compatible - como indican los trazos apagados de antiguas letras - con almacenes, tiendas y moradas familiares. En el medio del grupo que deja la casa camina el joven trajeado y de corbata, el tributante mayor de la excursión. En principio una parte de nuestros varones aborda un auto decapotado y es visible que van precedidos por otros dos que marchan en una "charrette", también típica del campo sureño. La última toma está llena de significados: desde el interior del auto se observa el paisaje rural y en él se destaca el perfil de una avioneta que seguramente aguarda a la mayor parte de este colectivo. Aires rotundos de modernidad y de confirmación de clase 0 al menos de vecindad con estructuras de poder, iquiénes pueden ser conducidos en avioneta a inicios de la década 1940 sino dueños de empinados recursos o funcionarios $?^{14}$ Señales de un país que acelera la híbridez entre lo arcaico y lo nuevo, lo tradicional y lo moderno, palco de tensiones sociales que anticipan la eclosión peronista, pero que persevera en mantener las matrices genéricas patriarcales. La cámara fálica nos introduce singularmente en los juegos preferenciales de la experiencia histórica masculina: constituir a las mujeres como objetos de deseo e inhibirlas de la libertad de deseo propio. La moral patriarcal no puede entonces sino ser doble. Sin embargo, los ángulos de esta cámara revelan, bajo la parsimonia de los estándares, indicios de las ambigüedades de sentido de los varones tanto como las fugas de su calidad de objeto de que son capaces las más objetivadas de las mujeres.

\footnotetext{
${ }^{14} \mathrm{Habrí}$ algunos indicios de que este grupo de varones pudiera estar vinculado a funciones públicas, probablemente al desenvolvimiento de medios oficiales, como sugieren algunas pistas brindadas por la investigación posterior a cargo de Ricardo Ceppi.
} 


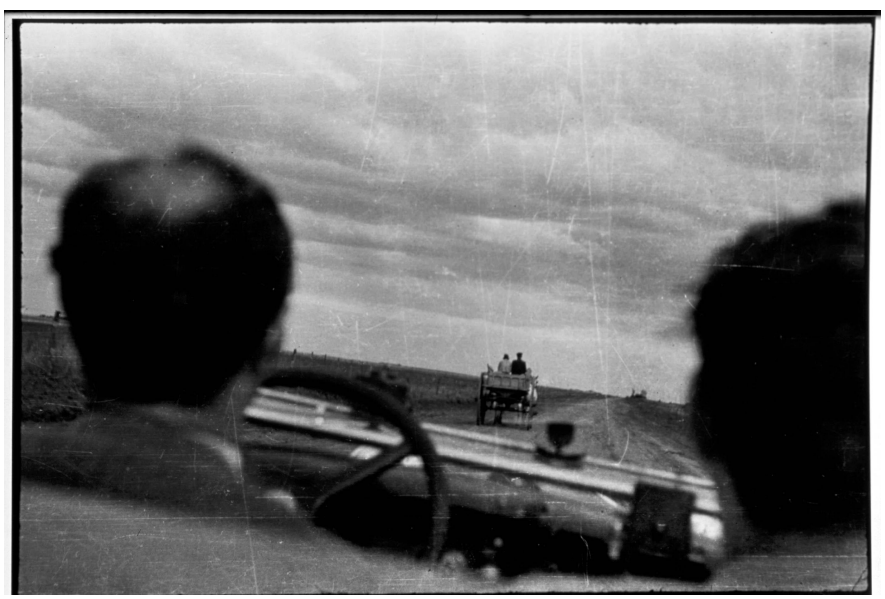

La fotografía, las imágenes infractoras y el(los) fotógrafo(s)

Desde su presentación al público ante la Academia de Artes y Ciencias del Instituto de Francia, el 19 de agosto de 1839, la fotografía fue figurada por François Arago por su capacidad práctica más que por su intencionalidad estética, aunque la veía "reproduciendo objetos de arte distantes a varios kilómetros y hasta construyendo mapas descriptivos del planeta, para ser analizados por los científicos en sus propios centros, evitando así las incomodidades del traslado de los investigadores o de las piezas mismas" ${ }^{\prime 2}$. Ni su propia imaginación podía adelantar los prodigios de que sería capaz el nuevo medio, el congelamiento del acontecer como elemento primordial de la memoria. Ceremonial, hierática, retratista - con enorme conciencia sobre su sentido de "posteridad" - tal la primera disposición de la imagen fotográfica en las primeras décadas de su aparición.

\footnotetext{
${ }^{15}$ Casaballe, A.B. y Cuarterolo, M.A. Imágenes del Río de la Plata. Buenos Aires, Editorial del Fotógrafo, 1983, p.6.
} 
Sexo-s en el lupanar

Con el paso del tiempo, los objetos de la fotografía saltaron de los retratos - primordiales en su original performatividad - para focalizar escenas y escenarios múltiples a medida que así lo hizo posible la capacidad técnica de que dispuso. Una incontable cantidad de imágenes impresas, sobre pequeños papeles presensibilizados, circularon por las manos de un público cada vez mayor a medida que el siglo XX se abrió paso. Inicialmente el notable artefacto de la cámara fotográfica y el gusto por las fotografías fue patrimonio exclusivo de la clase aristocrática, hasta que en su despliegue relativamente reciente, con el abaratamiento de los materiales y cámaras fotográficas, se extendió a las clases populares. La banalización de la fotografía probablemente coincidió con un sentido más efímero de los acontecimientos, pero debe admitirse que por mucho tiempo le fue reservado un aire casi sacramental, ya que lo que resulta querido como postrer es esquivo a significados evanescentes - indignos del rito de la memoria, una suerte un ajuste de cuentas que los sujetos se imponen con su propio pasado. De ahí que pueda inferirse que los usos "indignos" - o infractores, como preferimos- la captación de escenas escatológicas, o por lo menos obscenas o desarregladas, constituyen una rareza hasta fines del XIX en que la cámara inició, sin regodeos, su fijación en cuadros francamente transgresoras, registrando el objeto sexual por excelencia, las mujeres en actitud lasciva.

Producidas especialmente en Europa - pues no puede excluirse la censura de las casas especializadas en el revelado en países como el nuestro, hasta bien avanzado el siglo pasado- su circulación limitada no impidió que ingresaran, aunque con gestos crípticos, a algunos hogares bien establecidos. Koetzle y Scheid señalan que "la fotografía erótica se convirtió en el contrabando más socorrido de la era moderna". ${ }^{16}$ Pero lo cierto es que las series fotográficas de mujeres apenas vestidas, 0 mejor desvestidas, que se exhiben con audacia provocativa y con gestos

${ }^{16}$ KortZle, M. y SCHeId, U. Frivolidades parisinas... Op. cit., p.10. 
desenfadados persiguiendo fines eróticos, se prodigaron en las casas dedicadas a albergar servicios sexuales mercantiles. Así, en las compilaciones corrientes de fotografías que aluden a prostíbulos, podremos hallar fotos-tarjetas de mujeres desnudas que, para los inicios del siglo XX, giraban con cierta asiduidad dependiendo de la jerarquía de las casas de cita.

En la Argentina puede encontrarse una serie de postales eróticas coleccionables que la marca de cigarrillos "Yolanda" obsequiaba a sus fumadores en los quioscos, a cambio de las marquillas usadas. Estas imágenes, comparables a las elaboradas para fines publicitarios, pueden ser consideradas como una de las pocas fotografías "pornográficas" de la época. Pero en uno y otro caso, las escenas eran preparadas para tomas muy estudiadas en el interior de un estudio constituido por un espacio amplio, provisto de fondos pintados y equipamiento de flashes destellados a magnesio, o disponiendo de grandes ventanales que permitían el ingreso de abundante luz solar; todo bajo una rotunda hegemonía: la dirección artística del fotógrafo. Sin embargo, es importante subrayar que se trataba de escenas recreadas para el registro fotográfico, por lo cual no es posible asegurar que quienes posaban ante las cámaras desprovistas de ropas y en situaciones de elevado calibre carnal, fuesen mujeres que ejercieran la prostitución. Más bien se trataba de mujeres puestas a posar, probablemente las mismas modelos que inspiraban a las obras de pintura con trazos eróticos que produjeron las diversas corrientes plásticas de inscripción moderna. Por lo tanto aunque estas fotografías antiguas pudieron ser tipificadas como prostibularias, nada permitiría confirmarlo, aunque los espacios destinados al intercambio sexual resultaran los verdaderos "ámbitos de sentido" de la representación fotográfica - tal como podría asegurar Schut - toda vez que las retratadas parecían comportarse como prostitutas, remedo de la identidad de las otras mujeres, las que podían ser el "verdadero" objeto de deseo de los consumidores.

Si las mujeres que alimentaban la imaginación erótica no eran meretrices en estas series, sí hubo otro tipo de colecciones 
Sexo-s en el lupanar

con retratos de servidoras sexuales. Son las fotografías de prostitutas que debieron recurrir a los estudios de profesionales a fin de que ser debidamente incorporadas a su libreta sanitaria. Este fue producto - como es bien sabido - de un requisito solicitado por las autoridades sanitarias que, en resguardo de los clientes y a consecuencia de la proliferación de las enfermedades venéreas, ya desde fines del XIX impusieron una vasta tecnología de controles. Resultaron similares a las de cualquier otra fotografía de retrato carnet, para uso en documentos de identidad y muy probablemente no hayan sobrevivido, ya que las portadoras se encargaron de su eliminación.

Una serie documental en buena medida sobreviviente se refiere a las fotografías exhibidas en los prontuarios policiales. Tal como lo evidencian algunos archivos, en las localidades de pequeño porte de la Argentina se produjeron retratos de meretrices "in situ", ya que las comisarías locales arrendaban los servicios de algún fotógrafo para realizar el trabajo en los mismos burdeles evitando la exhibición de las oficiantes. Pero en las grandes ciudades, es muy probable que se las citara y que las tomas fotográficas se realizaran en las propias instituciones policiales. Lo cierto es que allí donde se conservan mejor los archivos policiales en nuestro medio, es posible dar con estas series de meretrices retratadas.

Pero más allá de este cuadro inicial, debe concluirse que no contamos en la Argentina con un fondo documental de fotografías que ilustren sobre las conductas ejercitadas en los prostíbulos, y que por lo tanto el registro fotográfico ahora presentado, tiene características inéditas. Luis Priamo afirma que

es muy difícil encontrar documentos fotográficos que descubran o revelen aspectos sórdidos o "feos" de las personas. Si debiéramos guiarnos por los documentos fotográficos disponibles, la prostitución, por ejemplo, no existió en nuestro país, ni siquiera cuando estuvo legalmente habilitada - y puedo asegurar que este tipo de 
Dora Barrancos e Ricardo Ceppi

fotos fueron y son de las más buscadas por investigadores y editores. ${ }^{17}$

Un antecedente en materia de captación de imágenes directas tuvo como protagonista al pintor Antonio Berni quien confesó haberse inspirado para la creación de su célebre Ramona Montiel. En 1931 - después de su primer viaje a Europa - se hizo amigo de Rodolfo Puiggrós, un periodista rosarino como él mismo, quien tuvo la idea de hacer una nota sobre los prostábulos de Rosario llevando a Berni como fotógrafo. El pintor disimulaba su cámara fotográfica ocultándola bajo un sombrero y sobre la mesa en el salón de espera, mientras tomaba discretas fotografías de las negociaciones previas que se sucedían entre los parroquianos y las habitantes de la casa de citas. Recordaba B erni:

Los mejores quilombos de Rosario estaban en la calle Pichincha, había de dos pesos, de tres pesos y de cinco pesos. Luego estaban los de un peso, pero esos quedaban en la calle Suipacha y eran los más rascas. Lo corriente es que fueran grandes patios que habían sido techados con vidrio, de modo que, de día, eran muy luminosos. Comenzaban a funcionar a partir de las 4 de la tarde, así que hasta las 6 , sobre todo en verano, tenían una luz bárbara. Yo saqué una cantidad de fotografías, Puiggrós eligió cinco o seis y las publicó, junto con su nota. Los documentos fotográficos de esa época, los guardé durante mucho tiempo, pero un día desaparecieron; yo creo que alguien me los robó. Y tenía muchísimo material porque yo continué, por mi propio interés, la documentación de los prostíbulos y de muchas otras cosas más. Ramona Montiel viene un poco de ahí. ${ }^{18}$

\footnotetext{
${ }^{17}$ Luis Príamo, "Fotografía y Vida Privada", en Fernando Devoto y Marta Madero (Directores), "H istoria de la Vida Privada en la Argentina", T 2, Buenos Aires, Taurus, 1999, p.281.

${ }^{18}$ Antonio Berni, entrevista de Rodolfo González Arzac en Revista "La Maga", edición especial dedicada a Rosario, 1 de mayo de 1997.
} 
No es posible identificar la publicación donde Puiggrós publicó las imágenes y menos aún dar con la serie completa que Berni realizó y que luego se le fue de las manos. ¿Qué habría retratado Berni? ¿Habría llegado su lente a algo más que las escenas de pre-trato entre los clientes y las servidoras? ¿El foco alcanzó a retener escenas explícitas de intercambios sexuales? Es dudoso.

La crítica teórica sobre el arte fotográfico, tal como lo señala Philippe Dubois ${ }^{19}$, ha reparado por lo menos en tres perspectivas cuando se trata de apreciar el "principio del realismo" conferido a las imágenes: la fotografía como mímesis de lo real (espejo, concordancia, similitud absoluta), la fotografía como una traducción (transformación de lo real en un nuevo código), y por último, como indicio, huella, mera impresión de lo real sujeto al trabajo de la deconstrucción o transformación completa de lo real. Adoptamos un punto de vista heteróclito, acertando con Dubois, que la fotografía implica "singularidad, atestiguamiento y designación". André Bazin ha señalado "La originalidad de la fotografía respecto de la pintura reside en su objetividad esencial"20. El análisis del archivo que nos ocupa permite concluir que no hay dudas de que estamos frente a un documento exponencialmente "singular, testimonial y designativo", como expresa Dubois y que refiere un "índice" del oficio de prostitutas en explícita relación con clientes -, ofreciendo un carácter de incontestable veracidad, de entera asimilación al acontecer real. Testimonia de manera crucial el acerbo en el que la serie fotográfica es compilada, tanto como el contexto en el que se sitúa la interacción que la lente ha congelado. Pero en cualquier situación expresada por la fotografía, esta no sería la única fuente capaz de brindar certeza so bre el verismo que pretende afirmar. La fotografía no enuncia una realidad absoluta, sino un aspecto o un fragmento de esa realidad, como coinciden varias fuentes teóricas.

\footnotetext{
${ }^{19}$ Dubols, Philippe. El acto fotográfico. De la representación a la presentación. Barcelona, Piadós, 1986.

${ }^{20}$ apud ID., IB., p.30
} 
¿Qué sería necesario para que una fotografía represente por sí misma la realidad que traduce como documento? Para que ello ocurra es necesario deparar con un material donde el acto fotográfico haya retenido el preciso instante del devenir de una acción.

El documento descubierto se refiere a fotografías del estilo "directas", que contaron en su mayoría con la aprobación explícita de los retratados mientras otras tomas se realizaron subrepticiamente. Obtenidas sobre todo en el interior del piringundín de marras, una de las imágenes resulta central (la que corresponde a la fo to 9 de la serie) y que ha sido objeto demorado de análisis - se trata del acto de masturbación que protagoniza uno de los participantes (identificado como la figura prominente, cuya equiparación lingüística sería el "no marcado" de la serie), escena que transcurre en el patio central de la casa ante la presencia de terceros, 0 al menos de quien porta la cámara fotográfica. El realismo del acontecimiento que sobrevive en la imagen no deja dudas sobre la veracidad de los comportamientos. No existían para esos años técnicas de digitalización, similares a las actuales, que permitieran la alteración del contenido de las imágenes, y además, porque la fuente encontrada es de un negativo analógico, original y único. Esta audaz fotografía confiere autenticidad a las restantes, permitiéndonos realizar una lectura de la totalidad de las escenas, en su forma de historia o secuencia fotográfica, que se constituye en una prueba documental, en un acontecimiento remisivo que permite recrear el pasado como si se lo estuviera viviendo.

A seguran Casaballe y Cuarterolo:

La fotografía fue reconocida desde el momento de su presentación como un modelo de registro objetivo de la realidad. (...) Esa capacidad de reproducción de los objetos reales en un plano bidimensional, con una notable riqueza 
Sexo-s en el lupanar

de detalles - capaz de ver incluso aquello que escapa al ojo más escudriñador - , la convierte en un casi indiscutido. ${ }^{21}$

Ciertamente, la cámara registró de modo mecánico objetos en cada una de estas fotografías y nuestra observación permite retener algunos signos que dan marco a la serie, confirmando que estamos en presencia de fotografías que transcurren en un "espacio público destinado a servicios muy privados", identificado sin hesitación como lupanar, burdel, casa de citas, o como quiera llamárselo. Recorramos algunos íconos:

a) Los escasos objetos de decoración presentes en el patio, la disposición de bancos contra las paredes de la galería y las mesas dispersas permiten suponer que estaban así distribuidos para que los visitantes esperaran su turno (fotos numeradas 4 a 25)

b) El servicio de bebidas y platos de comida sobre mesas cuadrangulares, relativamente pequeñas, como las usadas en bares y otras casas del ramo, sugieren que se trata de un lugar donde se brindaban servicios destinados a públicos y no a miembros de unidades domésticas familiares (fotos 18, 19 y 20).

Otras tomas dan cuenta de la falta de jerarquía del espacio tanto como su confinamiento lo que induce a configurar la idea de "establecimiento de márgenes":

c) La escena donde una mujer llena con agua una jofaina en la bomba del patio (foto 22), suscita la idea de que no existiría agua corriente para la higiene personal en las habitaciones y que por lo tanto debía usarse palanganas (a las que en algunos casos seguramente se echaba permanganato, como asegura la vasta literatura disponible).

d) Las tres ventanas tapiadas que aparecen en el frente del edificio (foto 35), permiten concluir que se trata efectivamente de un lugar clandestino.

\footnotetext{
${ }^{21}$ Casaballe, A.B. y Cuarterolo, M.A. Imágenes... Op. cit.
} 
La temporalidad de la secuencia, también es un dato de gran significado para la identificación iconográfica del locus:

a) En la mayoría de los lupanares, los servicios se fraccionan por horas, tal la unidad de medida que regula centralmente la actividad. Una comparación de la fotografía de inicio (la número 1), con las últimas del relato (fotos número 30 , 31 y 32) permite concluir que tratándose de la misma pared y dada la sombra proyectada por el alero del techo, el sol ha recorrido escasas dos horas. Es el tiempo en que podemos suponer duró la visita. Seguidamente devienen las fotografías de la despedida y el viaje de regreso que denotan sin ambages el fin de los hechos significados por las tomas.

Otras dimensiones son dignas de análisis y dicen respecto a las condiciones instrumentales de la operación y a la tecnología. Por la trayectoria de la luz es posible aseverar que el rollo fue expuesto en una sola instancia y refleja exclusivamente la visita que el grupo masculino realizó al prostíbulo. En total la serie muestra cinco mujeres, tal vez el conjunto completo de servidoras de la casa.

La calidad de la lente empleada en cámara fotográfica facilita una lectura nítida de las letras del diario que portaba uno de los varones. Posiblemente la cámara empleada fuera una Leica o una Contax; se trata de las primeras cámaras en el formato de 35 milímetros y esto resulta conclusivo para afirmar que si hay dificultades para situar con precisión el año de en que se produjo la serie, las tomas no pudieron ser anteriores a 1925 fecha en que las cámaras aludidas comienzan a comercializarse.

Es en los inicios del siglo XX cuando los desarrollos técnicos, al servicio de las cercanas contiendas mundiales, se orientaron en tres sentidos: ópticas más luminosas, películas más sensibles a la luz y cámaras fotográficas más pequeñas (...) En 1913, la fábrica alemana Leitz, desarrolló los prototipos de las cámaras LEICA, de pequeño formato y que permitían el uso de película de cine de 35 milímetros rebobinada, pudiendo obtenerse hasta 36 fotogramas en 
Sexo-s en el lupanar

una sola carga, saliendo a la venta al público en 1925.

Pequeña, discreta, portátil permitía obtener fácilmente imágenes instantáneas de objetos en movimiento. ${ }^{22}$

El rollo de negativos, donde se plasmaron las fotografías, corresponde a la película Agfa-Pankin, cuya fabricación se hacía en Alemania gracias a la firma Agfa-Gevaert a partir de 1929 para ser usada en cinematografía. ${ }^{23}$ Se trata en este caso de una película rebobinada.

Finalmente, nos adentraremos en el punto de vista del fotógrafo que actuó de manera central. La relación entre quien ejerce el dominio de la cámara - y de la escena - y los sujetos/objetos de la fotografía ha sido muy analizada. Percibir que somos objeto de una focalización fotográfica genera una sensación de exposición que se asimila con la de riesgo; en el instante de ser captados por la lente de una cámara sabemos que se tratará de nuestra imagen, la que detenida y perecedera, quedará expuesta a la consideración de los otros. En este acto de comunicación, no puede omitirse la carga emocional que imprime el fotógrafo: en él recae la responsabilidad de la representación, está en sus manos "el encuadre y el momento" de la toma. Es el fotógrafo - su mirada - quien realiza la selección de las circunstancias que se congelarán como cortes del continumm real y cuya interpretación de "acto violento" 24 no ha faltado. Actúa en él lo aprehendido, su propia carga psicosocial de sujeto histórico y por lo tanto no falta un reconocerse a sí mismo como un ser en situación, mediador/traductor de determinadas configuraciones de cultura. ¿Qué duda cabe en este caso sobre su entera complicidad con los estándares de género? La cámara, que como se ha dicho resulta el verdadero objeto de deseo en esta experiencia, funge como

${ }^{22}$ Catálogo Leica- Camera AG, Oskar-Barnack Strasse 11, Solms, Germany. 1999, pp. 4, 5 y 6.

${ }^{23}$ apud Catálogo AGFA-GEVAERT, marzo 2000, Andrew Huebscher, "H istory of Motion Picture Films"

${ }^{24}$ DuBois, P. El acto fotográfico... Op.cit., p.158. 
fetiche sexual en la mano para el fotógrafo. No hay dudas sobre la voluptuosidad que se activa en la manipulación del artefacto, sensaciones magistralmente recreadas por Denis Roche:

En el horror del momento ineluctable en que el index curvado y rígido va apoyarse sobre el disparador (...), en la brutalidad del golpe del pulgar que hace progresar la película muesca tras muesca, cosa que siente bien la falange (...), encadenado desesperadamente foto tras foto, como en esa carrera siempre retenida que hace que apenas se ha gozado haciendo el amor, no se piense en otra cosa que volver a hacerlo, ya tendido hacia el nuevo momento en quela carga, la plena carga esté en juego otra vez... ${ }^{25}$

Piénsese en el doble encadenamiento de la sensualidad cuando el referente constituye un estímulo decididamente cifrado en la sexualidad.

$\mathrm{H}$ ay algunas conductas observadas por el fotógrafo en esta serie que no pueden pasarse por alto, a saber:

a) La censura impuesta a la acción masturbatoria (¿Resulta objeto de una fantasía destructura que lo penitencia?)

b) Se ha escondido para obtener una fotografía de una de las parejas "de márgenes", agachándose detrás de una pajarera apoyada sobre una silla (foto 18). Concluye la serie con otras dos tomas seguidas, en donde esta misma pareja se abraza y que fungen como haber violado secretamente su intimidad (fotos $19 \mathrm{y}$ 20). Podría caber la hipótesis acerca de un contacto sexual de penetración experimentado por esta pareja, en uno de los cuartos, ya que fue retratada en una de las puertas. Si esto ocurrió, el fotógrafo se censuró más aún ya que, por la escasa sensibilidad de las películas (Agfa pankine - circa 21 din), podía haber utilizado flashes de magnesio para la iluminación artificial (aunque no hubiera podido evitar las consabidas explosiones y humo que ocasionaban).

${ }^{25}$ apud DuBo IS, P. El acto fotográfico... Op.cit., p.70. 
Sexo-s en el lupanar

c) Se destaca el sobrerregistro de la muchacha que ha realizado la masturbación al joven que hegemoniza la aventura: a ella le dedica 16 fotogramas, la mitad del material producido. Como ya fue dicho, la quiso retratar posando para él y su cámara, luego que cambió sus atuendos, en dos tomas (una de medio cuerpo y otra entera), lo que por cierto constituye un documento dentro del documento. La rescató en su mejor apariencia, o mejor dicho, cedió a un acuerdo tácito según el cual la muchacha pudo "representarse" de otra manera.

El fotógrafo ha inventado una historia que orilla la disposición cinematográfica ya que dirige cierta actuación, sobre to do referida a los protagonistas varones con quienes mantiene entera complicidad. Una apreciación de la serie completa permite advertir que los fotogramas rinden los signos de la fotonovela una vez que se impone una cierta teatralidad.

Es de toda evidencia que quien hegemonizó el uso de la cámara no dio pruebas de mayores conocimientos en el arte fotográfico, por lo que la autoría debe adjudicarse a un fotógrafo amateur primario, con conocimientos básicos de iluminación. Por cierto un ufano propietario del artefacto - o por lo menos con potestad sobre él - que se arrogaba congelar el tiempo. Pero no puede descartarse la actuación sustitutiva de otro fotógrafo, seguramente menos avezado que el protagonista central. Hay por lo menos dos escenas que acusan un dominio menos diestro de la cámara, pero parece irrefutable que este relevo es emergencial y que la cámara infractora vuelve a las manos del que funge con más experiencia, de quien casi con certeza se arrogará la creación de estas imágenes objeto de interdicción.

Coda

La naturaleza de este documento subraya su carácter raro, difícilmente dispuesto en los fondos memorísticos fijos, en los archivos privados y mucho menos en los públicos. Los intercambios carnales sólo de modo reciente (cuando se tornaron 
espectáculo gracias a la industria mediática) han sido objeto de percepción indiscriminada. En la época de esta serie fotográfica azarosa, las imágenes lascivas, las representaciones de los deleites del cuerpo, observaban un resguardo críptico. Y aunque circularon toda suerte de imágenes eróticas con asomos pornográficos, en una enorme proporción constituyen "poses", gestos artificiales, fórmulas estudiadas de la disposición del cuerpo y de las partes erógenas. En buena parte las actrices-modelos sólo en apariencia resultaban oficiantes de la prostitución. En general, esas series observan la más pertinente simulación de quienes eran puestas a actuar. La serie fotográfica hallada por casualidad revela un acontecimiento, con visos de "realidad", y por lo tanto le es ajena la treta del "como si". La plausibilidad de los actos que se desarrollaron en un lupanar fueron registrados "verídicamente" por una cámara que casi con certeza recién se inauguraba en las manos de un representante de la clase media, o de alguien cercano a recursos de poder, muy probablemente a inicios de los 40 del siglo pasado. Los vínculos entre un grupo de mujeres "servidoras del sexo" y un conjunto de varones en tren de aventuras que le son ampliamente prerrogadas, transcurren en un lupanar de baja categoría en algún poblado de extramuros y permiten apreciar inmarcesibles relaciones de género. Los flujos de los comportamientos genéricos se sitúan más allá de la "objetivación" femenina en función de la mercantilización sometedora del sexo. Inequívocas asistencias maternales, propias de la condición femenina, surgen de estas prodigiosas fotografías. La actitud masculina de adoración a la técnica, en este caso la cámara fotográfica, es capaz de desplegarla como auténtico objeto de deseo. Y la astucia femenina de realizar maquínicas acciones masturbatorias, al punto de sustituirse como objeto, también es evocado y revivido por el congelamiento de la foto. La serie transgresora quedó seguramente dormida y silente en un oscuro reducto doméstico - lejos de la contemplación de aquellos seres que debían ser preservados. Seguramente cumplió un ciclo pragmático expresivo ya que sirvió para excitar a los varones en 
Sexo-s en el lupanar

un doble encadenamiento de canónica masculinidad: como prueba de la potencia sexual, como documento del poder de la cámara fotográfica. 